\title{
$\begin{array}{r}\text { business } \\ \hline R \text { E V I W } \\ \hline\end{array}$ \\ a journal of business administration discipline
}

\section{The Effects of Corporate Social Responsibilities on Financial Performance of Small and Medium Enterprises of Khulna City}

\author{
${ }^{1}$ Nusrat Zahan Lopa and ${ }^{2}$ Md Shakil Ahmad
}

\begin{abstract}
Purpose: Corporate Social Responsibility (CSR) is now a growing concern throughout the world. All type of firms i.e. large firms to small and medium firms are becoming aware about the term as it has found to be significantly associated with improving corporate image, which in turn influence overall performance of the firms. The main purpose of this study is to investigate the level of awareness of SME owners about CSR and also to identify the effects of CSR on financial performance particularly on Small and medium Enterprises (SME).

Methodology: Total 330 SMEs have been surveyed to achieve the objective of the study. Five variables has been used to determine SMEs' CSR activities i.e. activities on employees, customers, environment, country, community and society. To determine financial performance, data regarding sales and profitability of past five years is used. Correlation and regression is used to determine the effect of CSR activities on financial performance. Beside this, SME owners' perception has been summarized from open-ended question.

Findings: The study suggests that more than half of the SME owners (around 60\%) are aware about CSR, but they cannot give a concrete definition regarding it. From correlation analysis it was found that all the variables (activities on employees, customers, environment, country, community and society) have significant positive relationship with financial performance of SMEs. Regression analysis says that three variables e.g. CSR on employees, customers and environment has significant positive effect on financial performance of SMEs. Other two variables e.g. CSR on country and CSR on community and society have no significant effect on financial performance of the firms.

Originality/Value: This study summarized the SME owners' perception regarding CSR and their activities on CSR. No such study has been conducted in Bangladesh particularly on SMEs and influence of CSR activities on their financial performance.
\end{abstract}

Key words: Corporate Social Responsibility, SME, Responsibilities on Employees, Customers, Environment etc.

\section{Background of the Study}

SMEs are playing a vital role in economic development of a country and it is especially inevitable for developing countries like Bangladesh (Alauddin \& Chowdhury, 2015; Bakht \& Basher, 2015). As this sector is labor intensive with short growth period, it can increase national income by generating new employment opportunities for young entrepreneurs. Many countries in the world have focused on SME development for higher economic growth, narrowing the gap of income inequality and poverty alleviation (Chowdhury \& Ahmed, 2009). The economic, sociopolitical and environmental changes constantly taking place in the world of today have important effects in most organizations. In the race of winning customer's heart and improving company image, more and more companies are struggling toward reaching to their ultimate target where all the stakeholders will feel happy to be a part of the organization. This notion has lead to the inauguration of Corporate Social Responsibility concept, which ensures that all parties directly or indirectly involved with the organization will be benefited or at least will not be harmed by any activities of the organization (Orlitzky, 2013; Giannarakis \& Theotokas, 2011).

Corporate Social Responsibility (CSR) is usually defined as a company's obligation to all of its stakeholders across all of its activities with the aim of achieving sustainable development in the economic, social and environmental dimensions (Carroll, 1999; Masaka, 2008). Stakeholders can include employees, customers, suppliers, community organizations, the environment, subsidiaries and affiliates, local neighborhoods, investors and shareholders (Rahman, 2011;Van Marrewijk, 2003;Hack, Kenyon, \& Wood, 2014).The activities of CSR is not only limited to

\footnotetext{
${ }^{1}$ Associate Professor, Business Administration Discipline, Khulna University, Khulna-9208, email-nusratzahan.lopa@gmail.com

${ }^{2}$ Independent researcher, email:shakilahmad742@gmail.com
} 
Business Review- A Journal of Business Administration Discipline, Khulna University, Volume: 12, Number: 1E2, January-December 2017, pp.29-38 (Print ISSN : 1811-3788; Online ISSN : 2664-3502)

the economic, technical and legal requirements, but also the firms seek to accomplish social benefits by continuous commitment to behave ethically and contribute to economic development while improving the quality of life of the workforce and their families as well as of the local community and society at large (Matten, \& Moon, 2004). Financial performance refers to the level of performance of a business over a specific period of time, expressed in terms of overall profit and losses during that time. The connection between CSR and financial performance has remained unclear with literature showing contradictory information. To reveal the real picture of whether CSR can create or destroy business value, existing literature can be categorized into positive relationship (Lee, Faff, \& Langfield-Smith, 2009; Mustafa, Othman, \& Perumal, 2012; Weshah, Dahiyat, Awwad \& Hajjat, 2012), negative relationship (Becchetti \& Ciciretti, 2009; Lioui\& Sharma, 2012; Dianita, 2011) and no significant relationship (Linthicum, Reitenga \& Sanchez, 2010; Soana, 2011).

In some studies, CSR is linked with subsequent financial performance as to find out the degree at which financial performance is improved, also with past firm performance to explore if firms with high financial performance take on CSR actions. Based on this interrelationship that financial performance and CSR determines the magnitude of each other; Wad dock and Graves (1997) based on the theories of "slack resources" and "good management" proved that better financial performance results in improved CRS and improved CSR led to improved financial performance.

Though some researchers have been conducted on the relationship between CSR and firm performance, these studies have mainly focused on large companies or industries. As mentioned earlier, CSR and firm performance are interrelated and they have reciprocal relationship, it is obvious that large companies will undertake CSR activities in order to improve their image. The result is improved financial performance. But it is crucial to observe the CSR activities of Small and Medium Enterprises, as these companies have limited number of employees and profit level. Moreover, the awareness level of SME owners is also need to be investigated as SMEs are being considered an important driver of economic development especially for a developing country like Bangladesh. Considering the fact, this paper aims at investigating the awareness level of SME owners and managers. It also examines the relationship between firm performance and CSR activities (if any, either consciously or unconsciously) of SMEs.

\section{Objectives}

The main objective of this study is to identify the effect of Corporate Social Responsibility on Financial Performance of Small and Medium Enterprises. Beside this, it also investigates the perception and awareness of SME owners and managers regarding CSR and get an idea about how do they define CSR in their own way.

To measure the effect of CSR, five variables are used namely CSR on Employees, CSR on Customers, CSR on Environment, CSR on Community \& Society and CSR on Country. So the specific objectives to achieve the main objectives are as follows:

- To identify the effect of CSR on employees on financial performance of SMEs

- To identify the effect of CSR on customers on financial performance of SMEs

- To identify the effect of CSR on environment on financial performance of SMEs

- To identify the effect of CSR on community and society on financial performance of SMEs

- To identify the effect of CSR on country on financial performance of SMEs

\section{Literature Review}

Corporate Social Responsibilities: Historically, people operated business only for making profit and there were hardly any concepts relating to corporate social responsibility. Now, with the beginning of 20th century, business has broadened its limited scope to an extended arena. The market has widened and society has been enriched with the amenities from the business. The concept of corporate social responsibility has reached in a level that coincides combined approach of business towards the society. The literature suggests that the practice of CSR differs from country to country and between developed and developing countries (Ullah, 2013). Moreover the patterns of following CSR activities also vary between types of industry (Mustafa, Othman \& Perumal, 2012). Corporate social responsibility is an insight, whereby companies operations are integrated with social and environmental issues and interactions with their stakeholders are based on a voluntary basis (Crane, Matten \& Spence, 2013). Here companies 
Business Review- A Journal of Business Administration Discipline, Khulna University, Volume: 12, Number: 1E2, January-December 2017, pp.29-38 (Print ISSN : 1811-3788; Online ISSN : 2664-3502)

try to be socially responsible which means not only complying with legal requirements, but also going beyond that for the betterment of society, environment and all stakeholders as a whole (Alam, Hoque, Safiul \& Hosen, 2010). So it can be said that CSR is defined as the duty of the firm to allocate its resources in such a way that benefits the society and improves the welfare of society irrespective of direct financial or non-financial benefits for the company. Through CSR practices, companies can maintain a balanced relationship with all of its stakeholders including employees, customers, community and society with the environment and country as a whole. It is applicable in all types of companies and in all sectors of activity, from SMEs to MNCs.

CSR in Bangladesh: Though CSR has become a growing concern all over the world, this concept is still at its infancy and somewhat vague in Bangladesh, especially for small firms. Here most of the businesses are family owned and they do not maintain any concrete policy regarding CSR (Alam, Hoque, Safiul \& Hosen, 2010). However, the recent trend shows that there is considerable pressure from various agencies on companies to act responsibly as well as to be accountable for the impacts of their (companies) business activities on social, political and ecological environments. As a result many corporations, especially large companies started to implement some CSR practices beyond financial gain and legal requirements. According to Alam, Hoque\& Hosen (2010), CSR practice in Bangladesh was pioneered by multinational companies. Large companies integrate CSR activities into cross-border business practices which gradually become one of the determining factors to access in the market. However, CSR activities for small and medium firms are still in dark side and hence need to be researched.

Relationship between CSR and Financial Performance: As mentioned earlier, numerous studies found contradictory result regarding the relationship between CSR activities and firm performance. Wangs (2014) pointed that corporations' attitudes toward CSR mainly depend on the fitness of CSR with profits. Corporations will usually hold a positive attitude if their practice of CSR contributes to the increase of profits. Otherwise, they will hold a negative attitude towards CSR. Actually if the organization has less profit it hardly considers other activities besides business activities. Uma (2013) added that corporations can think of CSR as a limitation or an additional cost, although it may be an opportunity for them to innovate and gain a competitive advantage. Foote, Gaffney and Evans (2010) has criticized the money spend on CSR stating that the major responsibility of the managers is to maximize the profit of the organization as they contracted with the owners of the firm.

Raynard and Forstater (2002) mentioned that CSR is not always providing a positive impact on the financial performance; some cases showed that it could have a negative impact as well; while McWilliams and Siegel (2001) added that a lot of empirical studies showed that CSR and profitability can be engaged in a positive, negative or even neutral relationship. Raynard and Forstater (2002) stated that CSR can be seen as a way to reach the final goal of the organization which is increasing the shareholder returns but can't be considered as a goal itself. Companies should balance between scarifying some financial profit and satisfying its stakeholders at least on the short term (Anlesinya, Ahinsah, Bawa, Appoh, Bukari, 2014).

Sen (2011) mentioned that there are many criticisms of CSR by which managers try to ensure financial gain by developing different strategic forms of CSR. While Galant and Cadez (2017) pointed out that the CSR doesn't necessarily provide a stronger financial return nor does it produce weaker return, it depends on the techniques that are used to increase the financial return. So it can be said that CSR has three effects on financial performance such as positive, neutral and negative.

Small and Medium Enterprises (SME): The definition of SME varies from country to country and from industry to industry. Small and medium enterprises (SMEs) make up the vast majority of businesses in most countries (especially in developing countries like Bangladesh) and they provide a huge contribution in employment generation, alleviating poverty, economic growth, innovation and diversity (Alauddin,\&Chowdhury,2015).

According to the Central Bank of Bangladesh Small Enterprise refers to the firm/business which is not a public limited company and complies the following criteria: 
Business Review- A Journal of Business Administration Discipline, Khulna University, Volume: 12, Number: 1E2, January-December 2017, pp.29-38 (Print ISSN : 1811-3788; Online ISSN : 2664-3502)

Table 01: Small Enterprise

\begin{tabular}{|c|c|c|c|}
\hline Serial & Sector & $\begin{array}{c}\text { Fixed asset other than Land and } \\
\text { Building (Tk.) }\end{array}$ & $\begin{array}{c}\text { Employed Manpower (not } \\
\text { above) }\end{array}$ \\
\hline 1 & Service & $50,000-50,00,000$ & 25 \\
\hline 2 & Business & $50,000-50,00,000$ & 25 \\
\hline 3 & Industrial & $50,000-1,50,00,000$ & 50 \\
\hline
\end{tabular}

Source: (Bangladesh bank, 2011)

Medium Enterprise refers to the establishment/firm which is not a public limited company and complies the following criteria:

Table 02: Medium Enterprise

\begin{tabular}{|c|c|c|c|}
\hline Serial & Sector & $\begin{array}{c}\text { Fixed asset other than Land and } \\
\text { Building (Tk.) }\end{array}$ & $\begin{array}{c}\text { Employed Manpower (not } \\
\text { above) }\end{array}$ \\
\hline 1 & Service & $50,00,000-10,00,00,000$ & 50 \\
\hline 2 & Business & $50,00,000-10,00,00,000$ & 50 \\
\hline 3 & Industrial & $1,50,00,000-20,00,00,000$ & 150 \\
\hline
\end{tabular}

Source: (Bangladesh bank, 2011)

\section{Characteristics of SME:}

$\checkmark \quad$ Intertwined ownership and management

$\checkmark$ Motivated management/commitment, integration of tasks for worker, variation and improvisation

$\checkmark$ Few hierarchical levels, short communication lines

$\checkmark$ Few and simple procedures, personal, direct oral internal communication

$\checkmark$ Personal and close relationship with customers

$\checkmark$ Craftsmanship

$\checkmark$ Tacitness of knowledge

$\checkmark \quad$ Idiosyncratic perception (Sen, 2011)

As has been mentioned earlier, researchers has found mixed effect of CSR on firm's financial performance, this study selects SMEs to be investigated whether there is any effect of CSR activities on financial performance.Lee, Herold and Yu (2015) suggested that SMEs are motivated for CSR activities if they get business benefits and value for the firm. However SMEs engage in CSR activities over Community and Society when they perceive benefits for instance better business growth and customer loyalty. Environmental responsibility can also result in better financial performance in the form of cost reduction in the long term because customers prefer firms who are aware about the environment (Graafland, Mazereeuw and Schouten, 2012). Care for the environment can also bring a win of more contracts with clients. SMEs who pay their taxes in regular basis, maintain their business ethics and laws also gain positive financial performance because of their stability (Ahmed and Chowdhury, 2009). However, there are no studies on the effects of CSR on financial performance of SMEs in Bangladesh. So the present study focuses on this issue considering the importance of CSR, SMEs and financial performance of SMEs.

\section{Conceptual Framework}

According to GRI (2002), CSR activities should focus on both socio-economic field and environmental field. So it says that CSR is oriented into the following three aspects:

- $\quad$ Economic aspect, which deals with effective and efficient management of business activities

- Social aspect, which includes respecting societal and cultural norms and getting involved in political and cultural life.

- Environmental aspect, which focuses on following the business activities that is environmental friendly.

Researches from Clarkson (1995); Waddock et al. (2002); Brunk (2010) have suggested the following aspects Clarkson, 1995; Freeman, 1984; Waddock et al., 2002; Brunk, 2010):

(1). CSR on customer: Ensuring high quality products and services to provide maximum customers' satisfaction. 
Business Review- A Journal of Business Administration Discipline, Khulna University, Volume: 12, Number: 1E2, January-December 2017, pp.29-38 (Print ISSN : 1811-3788; Online ISSN : 2664-3502)

(2). CSR on employees: Ensuring fair evaluation, promotion and compensation for employees.

(3). CSR on environment: Adopting environmental friendly activities in order to support environmental sustainability into business operations.

(4). CSR on economy: Providing products and services with reasonable pricing to meet social needs, and the sharing of profits with investors.

(5). CSR on community: Engaging in charitable activities and sponsoring cultural, sporting and educational activities for the betterment of community.

Based on these studies, present study has selected five main dimensions of CSR activities i.e. activities over employees, activities over customers, activities regarding environment, activities for community and society and finally activities over country. These dimensions are independent variables whereas financial performance of SMEs is dependent variable.

\section{Methodology}

Target Population and Sampling: This study has been conducted on Khulna City, so all the SMEs of Khulna city are considered as population for the study. To select sample, non-probability sampling technique has been used for collecting data. A complete list of small and medium enterprises is not available and hence convenience sampling has been used for data collection. According to Sarmah \& Hazarika(2012) and Sarmah, Bora-Hazarika \& Choudhury (2013), sample size for unknown population with $95 \%$ confidence level is 384 . To achieve the target, total 400 questionnaires were distributed among the SME owners, within which 350 was collected. Among these, 20 surveyed questionnaires were incomplete hence not considered for analysis. So the total sample size of the study is 330.

Data Collection Method: This study is based on primary data. The data have been collected through survey on the questionnaire. 330 responses have been used for analysis which was collected from different areas of Khulna city based on convenience sampling.

Data Analysis Method: To achieve the objective of this study, correlation and regression have been used to measure the effect of CSR activities on firm performance whereas to investigate the perception and awareness of SME owners, qualitative technique is used to analyze open-ended question. The perceptions have been summarized on the basis of their focus point.

\section{Data Analysis and Interpretation}

Awareness and Perception regarding CSR: The first objective of the study is to investigate the level of awareness regarding CSR among the owner of SMEs. The following table shows the percentage of owners in respect of their awareness of CSR:

Table 03: Awareness of CSR

\begin{tabular}{|l|c|c|c|c|c|}
\hline \multirow{3}{*}{ Valid } & & Frequency & Percent & Valid Percent & Cumulative Percent \\
\cline { 2 - 6 } & Yes & 195 & 59.1 & 59.1 & 59.1 \\
\cline { 2 - 6 } & No & 135 & 40.9 & 40.9 & 100.0 \\
\cline { 2 - 6 } & Total & 330 & 100.0 & 100.0 & \\
\hline
\end{tabular}

From the above Table: 3, it can be seen that, majority of the owners (almost 60\%) knows or at least heard the term CSR. The respondents who know about CSR were asked to describe their understanding and perception of CSR through an open-ended question. Many of them said this is something beyond legal requirement and somewhat volunteer activities, which will provide some goodwill in longer future. That means they acknowledge that CSR has somewhat positive relationship with the financial performance a firm because goodwill is an asset which creates positive image and attracts more customers, hence improves financial performance. The perception of SME owners regarding CSR is summarized below:

Taking Care of Employees: Some SME owners defined Corporate Social Responsibility as caring about their employees. By caring, they meant providing as much facilities as possible. They added, employees are the main 
Business Review- A Journal of Business Administration Discipline, Khulna University, Volume: 12, Number: 1E2, January-December 2017, pp.29-38 (Print ISSN : 1811-3788; Online ISSN : 2664-3502)

driver of a business, so if they want to survive in long run, they have to hold on their employees with satisfied and favorable attitude toward company. According to their view, CSR in not providing financial benefits (salary, pay raise, bonus, and promotion) and non-financial benefits (equal treatment, adequate working hour, adequate leave) only, it means something more. Some owners said providing personal attention toward their needs, maintaining supportive atmosphere for workers and creating a home like environment is much more important to be responsible for employees.

Customer Satisfaction: Another important factor that was found on the basis of the perception of the owners of the SME is customer satisfaction. The respondents said that they always try to satisfy their customers, because customers are main driver of their business. Here the owners provided mixed opinion as increasing customer base is related directly with the financial benefits. Some owners said that making customers satisfied is not only related to profit maximization, but also improving image so that they can continue in long run and serve community and society. As customers are their main stakeholders, being responsible to customers is also regarded as CSR by many owners.

Providing Good Products and Service: Many SME owners think that providing good products and services for which their business is meant to be is termed as CSR. According to their view, it is their main duty to provide good quality product or service to survive in the market. Being responsible means keeping and maintaining all the promises that they made during their initiation. Without providing good products or services they cannot run their business let alone other activities. So they always try to provide quality products to their customers with quality service.

Being Responsible to Country: Many SME owners expressed their viewpoint that CSR is a broad concept and is not only related to their business, but also to the country as a whole. They said, showing responsible attitude through the business in all possible ways is termed as CSR; for example paying taxes on regular basis, following the rules and regulation of the country, following the business ethics etc.

Maintaining Good Relationship with Stakeholders: Maintaining good relationship with all the parties involved which is beyond compulsion is termed as CSR to many SME owners. Though they do not understand the term 'Stakeholder', but still they brought all the segments associated with the business in their definition. For more clarity, they provide examples of customers, suppliers, environment, and community etc. one respondent said as follows: "I think CSR means being responsible to all the parties involved with my business, directly or indirectly... and to be responsible, we have to maintain a fair relationship with them."

Regarding the way of maintaining good relationship, they provided examples as follows:

- Responding to customer complaints promptly

- Involving in charitable activities like donation or providing scholarship to meritorious students

- Taking care of environment so that there is no harmful effect on it from business activities

- Produce quality product or provide quality service

- Not hiding any information regarding product, service or business

- Not involving in any unfair competition, like negative words toward the competitors, advertisements meant to undermine other firms etc.

So in nutshell, it can be said that most of the firm owners are aware about the term CSR, but they do not have any clear or concise idea about it; but without knowing or knowing little they are engaging in CSR activities. Majority of them think that maintaining a good relationship with the employees and customers is CSR activities to them. They hardly involve in social activities and volunteer works. Although they pay taxes in regular basis which is the responsibility over country they added. There were some discussions regarding the possible effects of CSR on their business. Most of the SME owners expressed positive view regarding this and said it can improve image, increase sales and market share, improve employee attraction and retention and overall satisfy customers. But at the same time, it increases the cost, so they suggested a balanced approach to develop and carry out CSR activities so that it would not hurt financial performance.

Relationship between CSR Activities and Financial Performance: To measure the CSR activities, 5 variables were selected based on the previous researches i.e. CSR activities on employees, customers, environment, community and 
Business Review- A Journal of Business Administration Discipline, Khulna University, Volume: 12, Number: 1E2, January-December 2017, pp.29-38 (Print ISSN : 1811-3788; Online ISSN : 2664-3502)

society and finally country and to measure firm performance, increase in net profit and sales growth of previous 5 years were taken. The correlation among these 5 variables and financial performance of SMEs are shown below:

Table 04: Correlation amongst Activities and Financial Performance

\begin{tabular}{|c|c|c|c|c|c|c|}
\hline & 1 & 2 & 3 & 4 & 5 & 6 \\
\hline 1.Financial Performance & 1.000 & & & & & \\
\hline 2. CSR on Employees & $0.468 * *$ & 1.000 & & & & \\
\hline 3. CSR on Customers & $0.419 * *$ & $0.673^{*}$ & 1.000 & & & \\
\hline 4. CSR on Environment & $0.300 * *$ & $0.319 * *$ & $0.358 * *$ & 1.000 & & \\
\hline $\begin{array}{l}\text { 5. CSR on Community and } \\
\text { Society }\end{array}$ & $0.342 * *$ & $0.265 * *$ & $0.576^{*}$ & $0.520 * *$ & 1.000 & \\
\hline 6. CSR on Country & $0.356 * *$ & $.435 * *$ & $0.276^{*}$ & $0.389 * *$ & $0.387 *$ & 1.000 \\
\hline
\end{tabular}

From the table, it can be seen that, all the variables i.e. CSR on employees, customers, environment, community and society and country has positive correlation with the financial performance of the SMEs and its significant at 0.01 level.

The strongest positive correlation (0.468) was found between financial performance and CSR on employees. The questions that were incorporated under this variable were related to the welfare of employees including financial and non-financial benefits. The result suggests that if the firm is supportive towards its employees, that mean if the firm has CSR activities over its employees, it improves financial performance of that firm. The reason can be if the firm cares for its employees, employees are motivated to work hard for the organization which leads to better financial performance.

The second highest positive correlation (0.419) was found between CSR activities on customers and financial performance. The questions included under this variable focused on whether the firm provides clear and accurate information about its product and service, whether the firm is responsive towards customers' complaints and overall whether the firm is concerned regarding customers satisfaction. The reason of positive correlation between financial performance and CSR activities on customers is quite obvious and it also supports previous literatures that if the company values its customers, it can win the race of competition. The result is increased customer base and market share, as a whole, improved financial performance.

Other three variables i.e. CSR on environment, community and society also has significant positive relationship with financial performance of SMEs. That means if the company is responsible towards its environment, community, society and country, it can improve its image and goodwill which ultimately leads to better financial performance.

Table 05: Regression Analysis

\begin{tabular}{|l|c|c|c|c|}
\hline Variables & Standardized Beta & Significance & Tolerance & VIF \\
\hline CSR on employees & $.347^{* *}$ & .000 & .425 & 2.865 \\
\hline CSR on Customers & $.265^{* *}$ & .008 & .289 & 2.264 \\
\hline CSR on Environment & $.179^{* *}$ & .015 & .410 & 1.785 \\
\hline CSR on Community \& Society & .267 & .440 & .626 & 1.873 \\
\hline CSR on Country & -.117 & .378 & .587 & 1.926 \\
\hline R Square & 0.312 & & & \\
\hline F value & $19.436^{* *}$ & & & \\
\hline Durbin-Watson & 2.035 & & & \\
\hline
\end{tabular}

**. Significant at the 0.01 level (2-tailed).

The above table shows three variables i.e. CSR on employees, customers and environment have significant positive influence on financial performance of SMEs, as the beta coefficient is positive at $1 \%$ significance level. Other two 
Business Review- A Journal of Business Administration Discipline, Khulna University, Volume: 12, Number: 1E2, January-December 2017, pp.29-38 (Print ISSN : 1811-3788; Online ISSN : 2664-3502)

variables (CSR on Community \& Society and CSR on Country) do not have significant influence on financial performance. The regression analysis reveals that SMEs that are responsible towards their employees, customers and environment can significantly improve their financial performance. Though some SME owners have vague idea regarding CSR, when they were asked about responsible activities toward their stakeholders, they expressed positive opinion. As SMEs are operated in a narrow scope, their earnings and profit level is limited, so they cannot involve in CSR activities for country and society in a broader range, hence the insignificant relationship between financial performance and CSR on society and country.

From Table: 5, it can be seen that the independents variables explain $31.2 \%$ (R square $=0.312$ ) variation of dependent variable. Durbin-Watson statistic indicates serial correlation of the residuals which has a value of 2.035 for this study that is within the acceptable range (1.5-2.5) and it is close to 2.00. So it indicates that there is no auto correlation problem in the data i.e. error terms are not correlated. The F-value is significant at $5 \%$ level (sig. F = .000). This concludes that the regression model used in this study is fit for analysis or in other words, the model was adequate.

\section{Conclusions}

This study sets out to find the perception of SME owners about Corporate Social Responsibility. It also tries to investigate the relationship between CSR activities and firm performance. To achieve the objective, 350 SMEs have been surveyed among which total 330 responses was used finally for analysis purpose. The research framework for this study relied on five important factors which help to develop financial performance of small and medium enterprises. Those factors named employees, customers, environment, community and society and country have been identified from various past researches. Based on the result of the study, each factor has been found to be significantly correlated with the financial performance. The regression results have been shown the significant relationship of three variables named Employees, Customers and Environment with financial performance and it has been shown non-significant relationship of financial performance with Community \& Society and Country. This study reveals that majority of the surveyed SME owners (around 60\%) are familiar with the term CSR, though they cannot define it precisely. From open discussions, it has been discovered that they have mixed understanding regarding the definition of CSR and they believe that CSR activities can result financial benefits for their business.

This study will motivate SME owners to engage in CSR activities with broader range, as it has shown positive relationship with financial performance, which will be ultimately beneficial for the country. Beside this, it also focuses on lack of proper awareness regarding CSR concept among SME owners, so various authorities can arrange training and seminar for SME owners to develop their understanding and awareness about CSR, as most of the SME owners do not have formal education on business. Because SME owners have positive attitude toward CSR activities, if they can be made aware and motivated to involve in CSR activities, it can be great contribution for the economy and country as a whole. For future study, longitudinal research can be conducted to measure actual effect of CSR activities on financial performance. Moreover, some comparative studies can be conducted to investigate the difference between financial performance of firms which carry out and do not carry out CSR activities.

At the end, it can be concluded that CSR has become an integral part of corporate activities hence is getting attention all over the world from small to large companies. To sustain in the competitive market, it helps primarily to maintain and enhance long-term relationship with employees, customers and country as a whole and secondarily it improves image which results better financial performance. So every firm, whether small or large should try to adopt CSR activities based on its affordability for the betterment of themselves and country.

\section{References}

Ahmed, K. and Chowdhury, T.A. (2009), "Performance evaluation of SMEs of Bangladesh", International journal of Business and Management, Vol. 4, No. 7, pp.126-132.

Alam, S. M., Hoque, D., Safiul, S. M., \& Hosen, M. (2010), "Corporate Social Responsibility (CSR) of MNCs in Bangladesh: A case study on Grameen Phone Ltd.", Journal of Potuakhali University of Science and Technology, Forthcoming. Available at SSRN: https://ssrn.com/abstract=1639570 (Accessed on 29 April 2019 
Business Review- A Journal of Business Administration Discipline, Khulna University, Volume: 12, Number: 1E2, January-December 2017, pp.29-38 (Print ISSN : 1811-3788; Online ISSN : 2664-3502)

Alauddin, M. and Chowdhury, M.M. (2015), "Small and medium enterprise in Bangladesh-prospects and challenges", Global Journal of Management And Business Research, Vol. 15, No. 7-C, pp. 22-31.

Anlesinya, A., Ahinsah, J., Bawa, F., Appoh, E.W. and Bukari, Z. (2014), "The effect of corporate social responsibility on financial performance of MTN Ghana Limited", International Journal of Thesis Projects and Dissertations (IJTPD), Vol. 2, No. 1, pp. 56-69.

Bakht, Z., \& Basher, A. (2015), "Strategy for development of the SME sector in Bangladesh", Bangladesh Institute of Development Studies, Dhaka. SCP in Bangladesh, Vol. 131, pp. 32-45.

Bank, B. (2011), "Small and medium enterprise (SME) credit policies \& programmes", SME \& Special Programmes Department, available at: bangladesh-bank.org (Accessed on 23 April 2019).

Becchetti, L., \&Ciciretti, R. (2009), “Corporate social responsibility and stock market performance” Applied financial economics, Vol. 19, No.16, pp. 1278-1293.

Brunk, K. H. (2010), "Exploring origins of ethical company/brand perceptions - A consumer perspective of corporate ethics', Journal of Business Research, Vol. 63, No. 3, pp.255-262.

Carroll, A. B. (1999), "Corporate social responsibility: Evolution of a definitional construct", Business \& society, Vol. 38, No. 3, pp.263-276.

Chowdhury, T. A., \& Ahmed, K. (2009), "Performance evaluation of selected private commercial banks in Bangladesh", International Journal of Business and Management, Vol. 4, No. 4, pp. 72-89.

Clarkson, M. B. E. (1995),“A stakeholder framework for analyzing and evaluating corporate social performance",

Academy of Management Review, Vol. 20, No.1, pp. 92-117.

Crane, A., Matten, D., and Spence, L.J., (2013), "Corporate Social Responsibility: Readings and Cases in a Global Context", 2/e. Abingdon: Routledge, pp. 3-26.

Dianita, P. S. (2011), "Analysis of the effect of corporate social responsibility on financial performance with earnings management as a moderating variable", Journal of Modern Accounting and Auditing, Vol.7, No. 10, pp. 1028-1040.

Foote, J., Gaffney, N. and Evans, J.R. (2010), “Corporate social responsibility: Implications for performance excellence", Total Quality Management, Vol. 21, No. 8, pp.799-812.

Galant, A. and Cadez, S. (2017), "Corporate social responsibility and financial performance relationship: a review of measurement approaches”, Economic research-Ekonomskaistraživanja, Vol. 30, No. 1, pp. 676-693.

Giannarakis, G., \& Theotokas, I. (2011), "The effect of financial crisis in corporate social responsibility performance”, International Journal of Marketing Studies, Vol. 3, No. 1, pp. 23-32.

Graafland, J. and Mazereeuw-Van der Duijn Schouten, C. (2012), "Motives for corporate social responsibility", De Economist, Vol. 160, No. 4, pp.377-396.

Hack, L., Kenyon, A. J., \& Wood, E. H. (2014), “A critical corporate social responsibility (CSR) timeline: How should it be understood now', International Journal of Management Cases, Vol.16, No. 4, pp. 39-51.

Hair,Jr, J.F., Black, W. C., Babin, B. J., Anderson, R. E., \& Tatham, R. L. (2010), Multivariate data analysis: A global perspective, Pearson Education.

Hedberg, C.J. \& Von Malmborg, F. (2003), The global reporting initiative and corporate sustainability reporting in Swedish companies. Corporate Social Responsibility and Environmental Management, Vol. 10, No. 3, pp.153- 164.

Lee, D. D., Faff, R. W., \& Langfield-Smith, K. (2009), "Revisiting the vexing question: does superior corporate social performance lead to improved financial performance?", Australian Journal of Management, Vol. 34,No. 1, pp. 23-35.

Lee, K.H., Herold, D.M. and Yu, A.L. (2016), "Small and medium enterprises and corporate social responsibility practice: A Swedish perspective" Corporate Social Responsibility and Environmental Management, Vol. 23, No. 2, pp. 88-99. 
Business Review- A Journal of Business Administration Discipline, Khulna University, Volume: 12, Number: 1E2, January-December 2017, pp.29-38 (Print ISSN : 1811-3788; Online ISSN : 2664-3502)

Linthicum, C., Reitenga, A. L., \& Sanchez, J. M. (2010), "Social responsibility and corporate reputation: The caseof the Arthur Andersen Enron audit failure" Journal of Accounting and Public Policy, Vol. 29, No. 2, pp. 167- 179.

Lioui, A., \& Sharma, Z. (2012), "Environmental corporate social responsibility and financial performance: Disentangling direct and indirect effects", Ecological Economics, Vol. 78, pp. 102-113.

Masaka, D. (2008), "Why enforcing corporate social responsibility (CSR) is morally questionable", EJBOElectronic Journal of Business Ethics and Organization Studies, Vol. 13, No. 1, pp. 79-91.

Matten, D., \& Moon, J. (2004), “Corporate social responsibility”, Journal of business Ethics, Vol. 54, No. 4, pp.

319-334.

McWilliams, A. and Siegel, D. (2001), "Corporate social responsibility: A theory of the firm perspective", Academy of management review, Vol. 26, No. 1, pp.117-127.

Mustafa, S. A., Othman, A. R., \& Perumal, S. (2012), "Corporate social responsibility and company performance in the Malaysian context”, Procedia-Social and Behavioral Sciences, Vol. 65, pp. 889905.

Orlitzky, M. (2013), "Corporate social responsibility, noise, and stock market volatility", Academy of Management Perspectives, Vol. 27, No. 3, pp. 239-253.

Rahman, S. (2011), "Evaluation of definitions: ten dimensions of corporate social responsibility", World Review of Business Research, Vol. 1, No. 1, pp. 168-181.

Raynard, P., \& Forstater, M. (2002), "Corporate social responsibility: Implications for small and medium enterprises in developing countries", retrieved from http://www.unido.org/fileadmin/import/29959_CSR.pdf (Accessed on 23 April 2019).

Sarmah, H.K., Bora-Hazarika, B. \& Choudhury, G. (2013), An investigation on effect of bias on determination of sample size on the basis of data related to the students of schools of Guwahati. International Journal of Applied Mathematics \& Statistical Sciences (IJAMSS), Vol. 2, No. 1,pp.33-48.

Sen, S. (2011), "Corporate social responsibility in small and medium enterprises: application of stakeholder theory and social capital theory", ePublications@SCU, Southern Cross University.

Soana, M. G. (2011), "The relationship between corporate social performance and corporate financial performance in the banking sector", Journal of Business Ethics, Vol.104, No. 1, pp.126-135.

Ullah, M. S. (2013), "Corporate social responsibility practices in the banking sector in Bangladesh-An assessment", Bank Parikrama, Vol. 38, No. 3 \& 4, pp.133-145.

Uma, P. (2013), "Role of SMEs in economic development of India", Asia Pacific Journal of Marketing \& Management Review, Vol. 2, No. 6, pp.119-126.

Van Marrewijk, M. (2003), "Concepts and definitions of CSR and corporate sustainability: Between agency and communion", Journal of Business Ethics, Vol. 44, No. 2-3, pp. 89-102.

Waddock, S. A., \& Graves, S. B. (1997), “ The corporate social performance-financial performance link", Strategic Management Journal, Vol.18 , No. 4, pp. 303-319.

Waddock, S. A., Bodwell, C., \& Graves, S. B. (2002),"Responsibility: The new business imperative", Academy of Management Executive, Vol. 16, No.2, pp. 132-148.

Wang, S. (2014), "On the Relationship between CSR and Profit", Journal of International Business Ethics, Vol. 7, No. 1, pp.42-56.

Weshah, S. R., Dahiyat, A. A., Awwad, M. R. A., \&Hajjat, E. S. (2012), "The impact of adopting corporate social responsibility on corporate financial performance: Evidence from Jordanian banks", Interdisciplinary Journal of Contemporary Research in Business, Vol. 4, No. 5, pp.32-45. 